Rev. Biol. Trop., 48(2/3): 333-351, 2000

www.ucr.ac.cr www.ots.ac.cr www.ots.duke.edu

\title{
Disparity, decimation and the Cambrian "explosion": comparison of early Cambrian and Present faunal communities with emphasis on velvet worms (Onychophora)
}

\author{
Julián Monge-Nájera ${ }^{1}$ and Xianguang $\mathrm{Hou}^{2}$ \\ 1 Biología Tropical, Universidad de Costa Rica, San José, Costa Rica. Fax (506) 2075550; rbt @biologia.ucr.ac.cr \\ 2 Nanjing Institute of Geology and Palaeontology, Academia Sinica, Nanjing 210008, China; xghou @ pub.jlonline.com
}

\begin{abstract}
The controversy about a Cambrian "explosion" of morphological disparity (followed by decimation), cladogenesis and fossilization is of central importance for the history of life. This paper revisits the controversy (with emphasis in onychophorans, which include emblematic organisms such as Hallucigenia), presents new data about the Chengijang (Cambrian of China) faunal community and compares it and the Burgess Shale (Cambrian of Canada) with an ecologically similar but modern tropical marine site where onychophorans are absent, and with a modern neotropical terrestrial onychophoran community. Biovolume was estimated from material collected in Costa Rica and morphometric measurements were made on enlarged images of fossils. Cambrian tropical mudflats were characterized by the adaptive radiation of two contrasting groups: the vagile arthropods and the sessile poriferans. Arthropods were later replaced as the dominant benthic taxon by polychaetes. Vagility and the exoskeleton may explain the success of arthropods from the Cambrian to the modern marine and terrestrial communities, both in population and biovolume. Food ecological displacement was apparent in the B. Shale, but not in Chengiiang or the terrestrial community. When only hard parts were preserved, marine and terrestrial fossil deposits of tropical origin are even less representative than deposits produced by temperate taxa, Chengjiang being an exception. Nutrient limitations might explain why deposit feeding is less important in terrestrial onychophoran communities, where carnivory, scavenging and omnivory (associated with high motility and life over the substrate) became more important. Fossil morphometry supports the interpretation of "lobopod animals" as onychophorans, whose abundance in Chengjiang was equal to their abundance in modern communities. The extinction of marine onychophorans may reflect domination of the infaunal habitat by polychaetes. We conclude that (1) a mature ecological community structure was generalized during the Cambrian, and even biodiversity and equitability indices were surprisingly close to modern values; (2) the morphological diversity and geographic distribution of onychophorans indicate a significant pre-Cambrian evolutionary history which does not support the "explosion" hypothesis; (3) disparity among phyla was not as important as the explosion-decimation model predicts, but in the case of onychophorans, disparity within the phylum was greater than it is today and its reduction may have been associated with migration into the sediment when large predators evolved.
\end{abstract}

Key words: Disparity, decimation, "explosion", community ecology, feeding, habitat, fossil, Metazoa, evolution, Chengjiang, Burgess Shale, Cambrian, Recent, Costa Rica.

The evolution of the earliest metazoans has been the subject of debate in recent years, particularly regarding the speed of change and the diversity of general body plans (Hou and Bergström 1995, Fortey et al. 1996). Argu- ments have centered on how representative the fossil record is and the usefulness of techniques such as cladism and specially molecular analysis (Bergström 1986) whose varied results have shown it to be premature (Hou and 
Bergström 1995, Fortey et al. 1996, Abouheif et al. 1998, Valentine et al. 1999).

Early century attempts to place some difficult taxa into extant phyla were abandoned for the proposal of new phyla in the 1970's, but recent work with better fossil material resulted in another change of opinion, and now much material has been reassigned to known phyla (Hou and Bergström 1994, Hou et al. 1995, Fortey et al. 1996, Sprinkle and Collins 1998).

Limitations of the fossil record are less important when soft parts have been preserved (Hou 1999). "Lobopod" worms are among the most interesting animal groups found in Cambrian soft-bodied communities. For almost a century authors have disagreed about their taxonomic position, although recent studies have supported the hypothesis that they were early ancestors of onychophorans (Hou and Bergström 1995, Monge-Nájera 1995).

Modern onychophorans are part of terrestrial ecosystems in tropical and south temperate regions (Monge-Nájera 1994 a, b), but the Cambrian species were marine and basically tropical (Hou \& Bergström 1995, Monge-Nájera 1995, 1996).

The only detailed quantitative synecological study of a fossil community with onychophorans described Burgess Shale (B. Shale) of southwest Canada (Briggs and Whittington 1985, Conway Morris 1986). However, at that time no appropriate tropical data were available for comparison. Conway Morris (1986) basically compared B. Shale with temperate communities and concluded that they were similar, particularly in the proportion of predators, in the presence of a few species that dominate numerically, and when compared with modern deep sea communities, in the occurrence of certain types of ancient taxa (Conway Morris 1986).

It is now known that there are differences between tropical and temperate mudflat communities (for example, tropical communities tend to have smaller populations of each taxon and also individuals with smaller bodies: Alongi 1989, Vargas 1996, J.A. Vargas 1999 pers, comm.) and a more meaningful comparison of the Cambrian tropical community requires information about modern tropical biotas because the best known Cambrian faunas were tropical (Hou et al. 1991, Monge-Ná jera 1995).

In the last decade, the Chinese Chengjiang fauna mentioned only briefly in a 1985 review of Cambrian soft-bodied faunas or "lagerstätten" (Conway Morris 1985) has become a mayor source of significant discoveries, among them, six of the nine species of fossil onychophorans reliably described to date (Hou et al. 1991, Chen et al. 1995, Hou and Bergström 1997).

It includes marine fauna of approximately upper Atdabanian dating, about $10 \mathrm{mi}-$ llion years older than B. Shale, thus providing a unique view of a fauna that lived shortly after the so called "Cambrian explosion", a characteristic of the greatest interest even if such an "explosion" never took place (Fortey et al. 1996).

The Chengjiang fauna occurs in the Yu'anshan Member of the Lower Cambrian Qiongzhusi Formation in Yunnan Province, but it was first discovered in Chengjiang County, about $50 \mathrm{~km}$ from Kunming, the capital of Yunnan Province (southeast China). The good preservation of Chengjiang specimens significantly improved the reconstruction of several taxa (e.g. Hou et al. 1991, Hou and Bergström 1994, Hou et al. 1995, Rigby and Hou 1995). Despite the geographic and chronological distance, both sites have some genera in common and were dominated by arthropods; differing mainly in the rarity of deuterostomes (a chordate and a crinoid have been found recently, H.X., pers. observ. 1999) and the lower proportion of trilobites in Chengjiang (Hou et al. 1991).

This fauna included a variety of invertebrates preserved in extraordinary detail (Jin et al. 1993, Hou and Bergström 1994, Hou et al. 1995, Rigby and Hou 1995). Some of these have been identified as onychophorans, also known as "lobopods", "lobopodians" or "oncopodophores" (Hou et al. 1995, Monge-Nájera 1995, Chen et al. 1995). However, the 
identification of these animals, with which most authors from temperate countries are not familiar, is often difficult (e.g. Rhebergen and Donovan 1994).

This paper presents new data concerning the Chengjiang community and compares it and B. Shale with a similar but modern tropical marine site where onychophorans are absent, and with a modern neotropical terrestrial onychophoran community. Terrestrial communities are expected to be different from marine communities, and their inclusion here requires justification: the Coronado terrestrial community was included because this paper stresses our common group of interest: onychophorans, which were marine in the Cambrian and are terrestrial in the Present. We wanted to examine how the assemblages in which they have evolved differed from the beginning of the phylum to the present. The walking speed of Cambrian onychophorans is estimated and new data about the effect of sediment flattening in living onychophorans as well as morphometry are used to support the hypothesis that the fossils represent onychophorans. Even though the emphasis is on onychophorans, the analysis and the conclusions refer to whole animal communities and thus are of interest to readers outside the field of onychophorology.

\section{MATERIALS AND METHODS}

Community comparisons: The B. Shale reconstruction is from Conway Morris (1986). In all cases the trophic nucleus, i.e. the group of food consumers (in contrast with producers and decomposers) that are numerically dominant in the community was identified on the basis of individuals, for reliability (see Conway Morris 1986 for details about the trophic nucleus concept). For a modern marine mudflat community, Punta Morales (Gulf of Nicoya stuary, Pacific of Costa Rica) the graphs for feeding habit, trophic nucleus, number of genera and number of individuals are based on data in Vargas
(1987, 1988a). The fossil communities developed at a greater depth than the P. Morales community, but still within the photic zone, so the overall patterns (precisely the type of patterns studied here) are not expected to differ greatly, the main probable difference being the greater physiological stress in the intertidal P. Morales habitat (J.A. Vargas 1999 pers. comm.). Standard ecological indices, biodiversity $(\mathrm{H})$ and equitability $(\mathrm{J})$ were calculated from number of specimens per taxon reported by Vargas (1987, 1988a), Conway Morris (1986) and Hou et al. (1991). Habitat, fossilization potential and body length information was provided by Vargas (1995 pers. comm., Table 1). Biovolume was estimated from the Vargas collections and from ten samples collected by the senior author in November 1992 with a cylindrical corer (core area $17.7 \mathrm{~cm}^{2}$ ) to a depth of $15 \mathrm{~cm}$, preserved in $10 \%$ buffered formalin in sea water stained with Rose Bengal and extracted under a dissection microscope at $10 \mathrm{X}$ (same methods and place of Vargas 1987, 1988 a,b). To measure biovolume the specimens were submerged (after allowing preservative to evaporate) in a pipette with a known volume of $70 \%$ ethanol and measuring the difference in $\mathrm{ml}$.

The modern terrestrial community data are from a random sampling of macrofauna in Cascajal de Coronado, San José, Costa Rica $\left(83^{\circ} 57^{\prime} 37^{\prime \prime} \mathrm{W}, 10^{\circ} 00^{\prime} 18^{\prime \prime} \mathrm{N}, 1775\right.$ m elevation, riparian forest and cattle grassland). Details about the field methods and site appear in Monge-Nájera and Alfaro 1995). Their biovolume was measured by the pipette method described above. This fauna is not included in the comparison at the genus level because it was not possible to obtain detailed taxonomic determinations. Vouchers are deposited in the Museo de Zoología, Universidad de Costa Rica.

For counts and morphometry, the Chengjiang fossils were photographed by the junior author (HX) and illustrated with a camera lucida; measurements were made on the resulting enlargements and photographs. 
To estimate walking speed of the fossil taxa, which generally were smaller and with less legs than living onychophorans, the maxi- mum length and leg pair values known for fossils were used in a regression based on the lowest equivalent values for living species.

\section{TABLE 1}

Characteristics of a modern marine community (Punta Morales, Costa Rica).

\begin{tabular}{|c|c|c|c|c|c|}
\hline Taxon & Group & Habitat & Diet & $\%$ indv & $\%$ vol total \\
\hline Cyprideis pacifica & Crust & EV & $\mathrm{S}$ & 22.64 & 6.10 \\
\hline Coricuma nicoyensis & Crust & $\mathrm{EV}$ & $\mathrm{S}$ & 20.70 & 9.34 \\
\hline Mediomastus californiensis $*$ & Polyc & IS & $\mathrm{D}$ & 11.09 & 26.43 \\
\hline Turbellaria * & Platy & $\mathrm{EV}$ & $\mathrm{O}$ & 8.33 & 0.15 \\
\hline Paraprionospio pinnata * & Polyc & IS & $\mathrm{D}$ & 4.59 & 0.45 \\
\hline Lumbrineris tetraura $*$ & Polyc & IV & $\mathrm{D}$ & 3.58 & 0.05 \\
\hline Oligochaeta spl $*$ & Oligoc & IV & $\mathrm{D}$ & 3.32 & 0.05 \\
\hline Spiophanes soederstroemi $*$ & Polyc & IS & $\mathrm{D}$ & 2.55 & 0.06 \\
\hline Tellina rubescens & Mollu & IV & $\mathrm{D}$ & 2.01 & 13.58 \\
\hline Ceratocephale crosslandi $*$ & Polyc & IV & $\mathrm{C}$ & 1.94 & 0.87 \\
\hline Prionospio delta $*$ & Polyc & IS & D & 1.31 & 0.02 \\
\hline Neanthes succinea $*$ & Polyc & IV & $\mathrm{C}$ & 1.13 & 0.07 \\
\hline Glycinde armigera * & Polyc & IV & $\mathrm{C}$ & 1.06 & 0.06 \\
\hline Pectinaria californiensis * & Polyc & IS & $\mathrm{D}$ & 1.02 & 2.28 \\
\hline Bivalvia, juvenile sp. 1 & Mollu & IV & $\mathrm{D}$ & 0.81 & 21.34 \\
\hline Hemichordata sp. $1 *$ & Hemic & IV & $\mathrm{D}$ & 0.81 & 1.81 \\
\hline Linopherus sp. $1 *$ & Polyc & EV & $\mathrm{C}$ & 0.78 & 0.00 \\
\hline Pinnixia valerii & Crust & EV & $\mathrm{O}$ & 0.71 & 0.64 \\
\hline Acesta lopezi ${ }^{*}$ & Polyc & IV & $\mathrm{D}$ & 0.68 & 0.00 \\
\hline Glottidia audebarti & Brach & IV & $\mathrm{D}$ & 0.61 & 1.36 \\
\hline Tharyx parvus * & Polyc & IS & $\mathrm{D}$ & 0.58 & 0.00 \\
\hline Panopeus sp. 1 & Crust & EV & $\mathrm{O}$ & 0.51 & 0.22 \\
\hline Sigambra tentaculata $*$ & Polyc & IV & $\mathrm{C}$ & 0.44 & 5.41 \\
\hline Nephtys monroi $*$ & Polyc & IV & $\mathrm{C}$ & 0.43 & 0.17 \\
\hline Notomastus hemipodus * & Polyc & IV & $\mathrm{D}$ & 0.43 & 0.19 \\
\hline Tagelus bourgeoisae & Mollu & IV & $\mathrm{D}$ & 0.42 & 0.56 \\
\hline Ophiuroidea sp. 1 & Echin & IV & $\mathrm{D}$ & 0.42 & 0.23 \\
\hline Chone mollis * & Polyc & $\mathrm{ES}$ & $\mathrm{S}$ & 0.37 & 0.00 \\
\hline Ostracoda sp. 2 & Ostra & $\mathrm{EV}$ & $\mathrm{O}$ & 0.36 & 0.83 \\
\hline Magelona pacifica $*$ & Polyc & ES & $\mathrm{D}$ & 0.35 & 0.00 \\
\hline Nemertina sp. $1 *$ & Nemer & IV & $\mathrm{C}$ & 0.35 & 0.22 \\
\hline Dosinia dunkeri & Mollu & IV & $\mathrm{D}$ & 0.31 & 2.77 \\
\hline Ophiuroidea sp. 2 & Echin & IV & $\mathrm{D}$ & 0.31 & 0.80 \\
\hline Natica unifasciata & Mollu & EV & $\mathrm{C}$ & 0.27 & 3.14 \\
\hline Encope stokesi & chin & $\mathrm{EV}$ & D & 0.26 & 0.80 \\
\hline
\end{tabular}

Brach Brachiopoda, Crust Crustacea, Echin Echinodermata, Hemic Hemichordata, Mollu Mollusca, Nemer Nemertina, Oligoc Oligochaeta, Ostra Ostracoda, Platy Platyhelminthes, Polyc Polychaeta.

E Epifaunal, I Infaunal, S Sessile, V Vagrant.

C Carnivore, D Detritus feeder, O Omnivore, S Suspension feeder.

* Taxon without hard parts, indv individuals, vol volume. 


\section{RESULTS}

\section{Comparison of Cambrian onychophoran marine communities} with a similar modern marine community

Number of genera: In comparison with the modern community in which polychaetes have more genera than any other group (Fig. 1), both Cambrian communities were rich in genera of arthropods and poriferans. Chordates and molluscs also are more diverse today, while poriferans, priapulids, cnidarians and hyolithids are absent from the modern community. Biodiversity $\left(\mathrm{H}^{\prime}\right)$ and equitability $(\mathrm{J})$ indices were $\mathrm{H}^{\prime}=$ 2.094 and $\mathrm{J}=0.46$ in B. Shale (Conway Morris 1986) and $\mathrm{H}^{\prime}=1.10$ and $\mathrm{J}=0.57$ in Chengjiang.

Fossilization potential: When considering the 35 species that represent the majority of specimens in the modern community, the fossilization potential (i.e. proportion of taxa

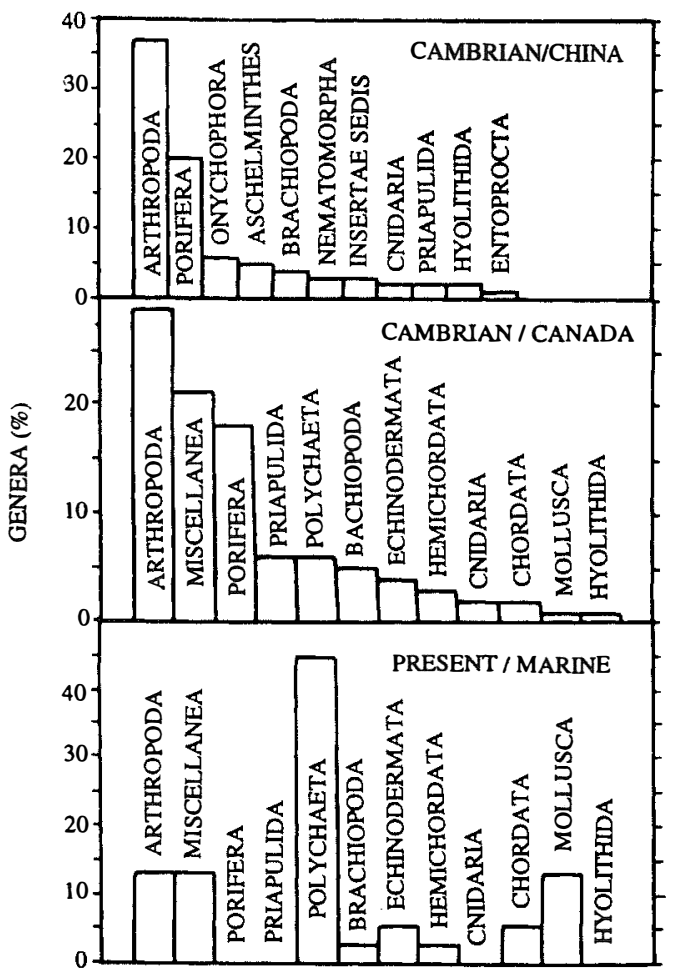

Fig. 1. Proportion (\%) of genera per taxon in marine Cambrian and modern communities. with hard parts that are likely to fossilize) is high in $14 \%$ (bivalve and gastropod molluscs), intermediate in $26 \%$ (brachiopods, echinoderms, arthropods) and low in $60 \%$ that have only soft parts (polychaetes, turbellarians, oligochaetes, hemichordates and nemerteans) (see Vargas 1987, 1988 b). If individuals rather than species are considered, only $4 \%$ have a high fossilization potential (Vargas 1987, 1988 b). Thus, individuals are more likely to be underestimated than species or higher taxa.

Albeit the fossilization potential for B. Shale species was not reported (Conway Morris 1986), most genera were monospecific (Hou et al. 1991) so the value for high fossilization potential is close to $14 \%$, much lower than in Chengjiang (50\%) and the modern community $(40 \%)$. By contrast, only small fractions of individuals had a good probability of fossilization in B. Shale (2\%) and the modern community $(4 \%)$ against a very high proportion $(90 \%)$ in Chengjiang.

Individuals and biovolume by taxa: The Chengjiang population was more clearly dominated by arthropods ( $84 \%$ ) than the B. Shale population $(61 \%)$. Arthropods were dominant in the three communities (Fig. 2), but in contrast with the Cambrian, in the modern community polychaetes are the second group in importance instead of hemichordates. B. Shale biovolume was dominated by arthropods, with poriferans, echinoderms and priapulids following. Molluscs and polychaetes dominate biovolume in the modern marine community, followed by arthropods.

Habitat: The sessile infauna was more common in B. Shale than in Chengiiang. In number of individuals, the Cambrian communities were dominated by epifaunal vagrant taxa, while in comparison the modern community is rich in infaunal vagrant taxa, has less epifaunal vagrant species and lacks sessile groups (Fig. 3). The same applies to biovolume except for B. Shale where sessile epifauna dominated. 


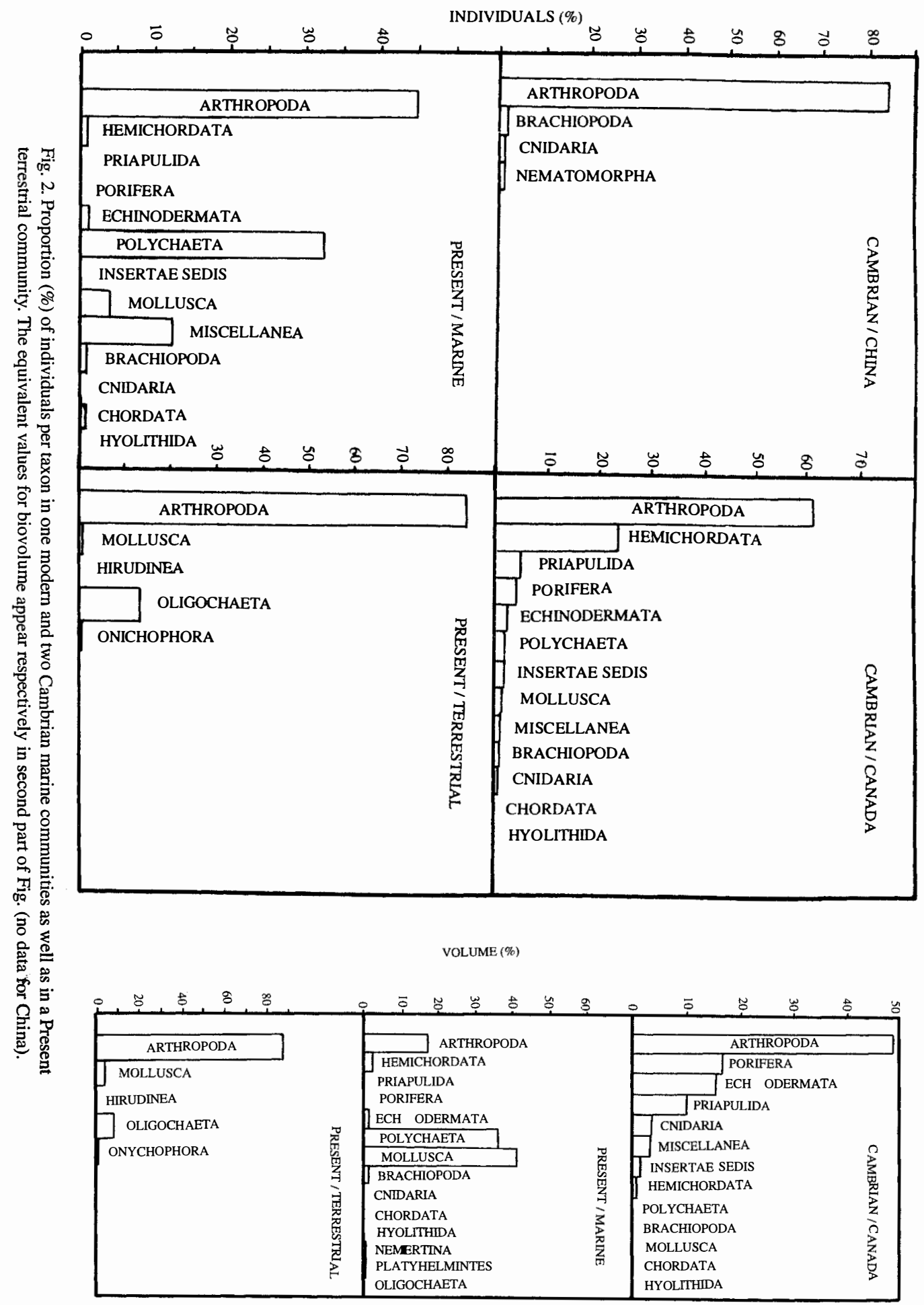



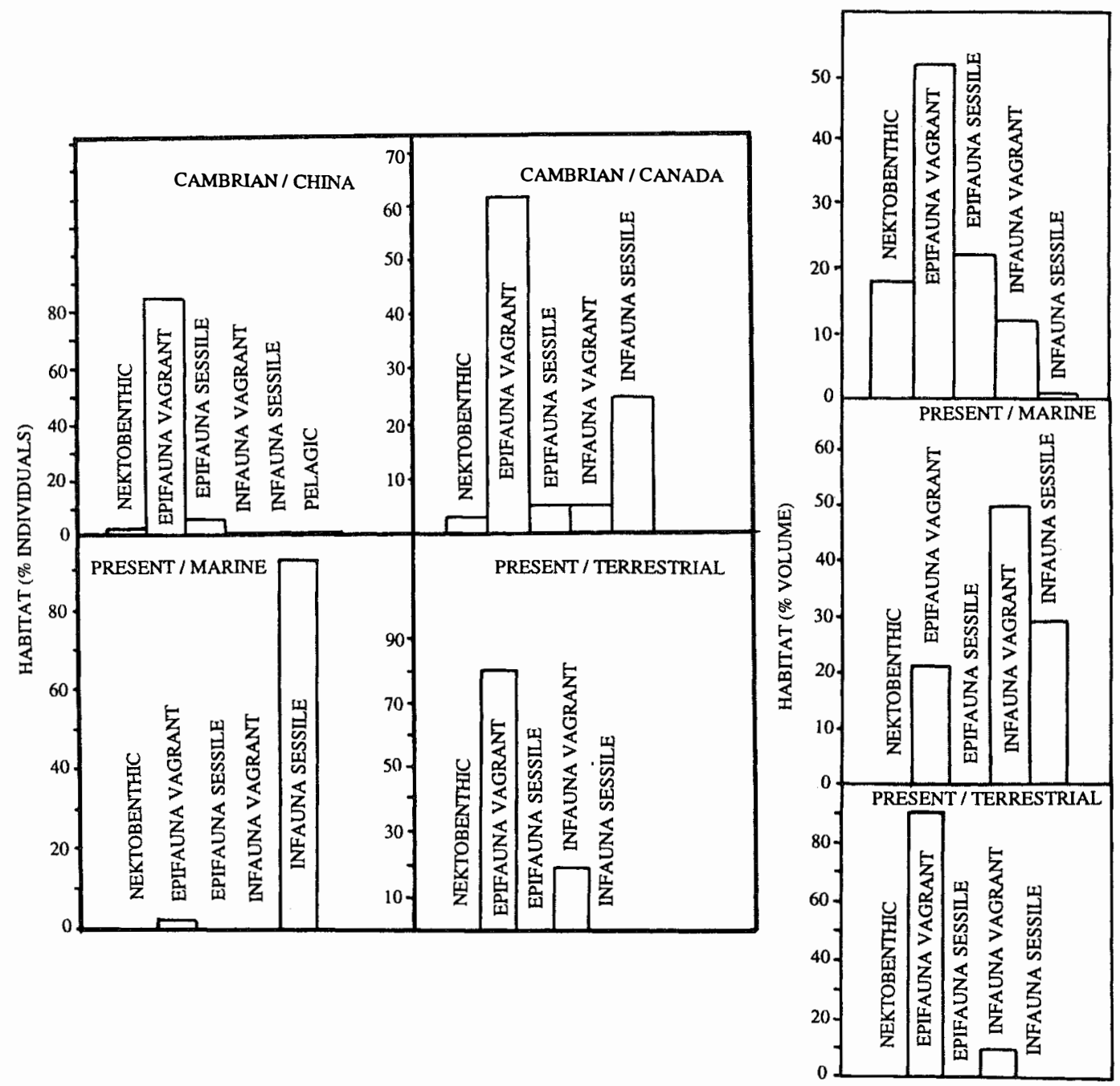

Fig. 3. Proportion (\%) of individuals occupying each habitat in marine Cambrian communities, and modern marine and terrestrial communities. The equivalent values for biovolume appear in second part of Fig. (no data for China).

Feeding habit: Deposit feeders were numerically dominant in all communities, but in the modern community the number of suspension feeders decreased while that of camivoresscavengers increased (Fig. 4). Two categories, omnivores and herbivores, were not identified in the Cambrian sites. Community biovolume was divided almost equally among all feeding habits in B. Shale, but deposit feeders dominate biovolume in the modern community.
Trophic nucleus: Arthropods dominated the trophic nucleus (as defined above) in all communities (Fig. 5). Hemichordates and priapulids are absent from the modern nucleus, in which polychaetes and turbellarids are important. In the modern community numeric domination is less extreme because two groups (Cyprideis and Bodotriinae) have similar proportions in the nucleus. 

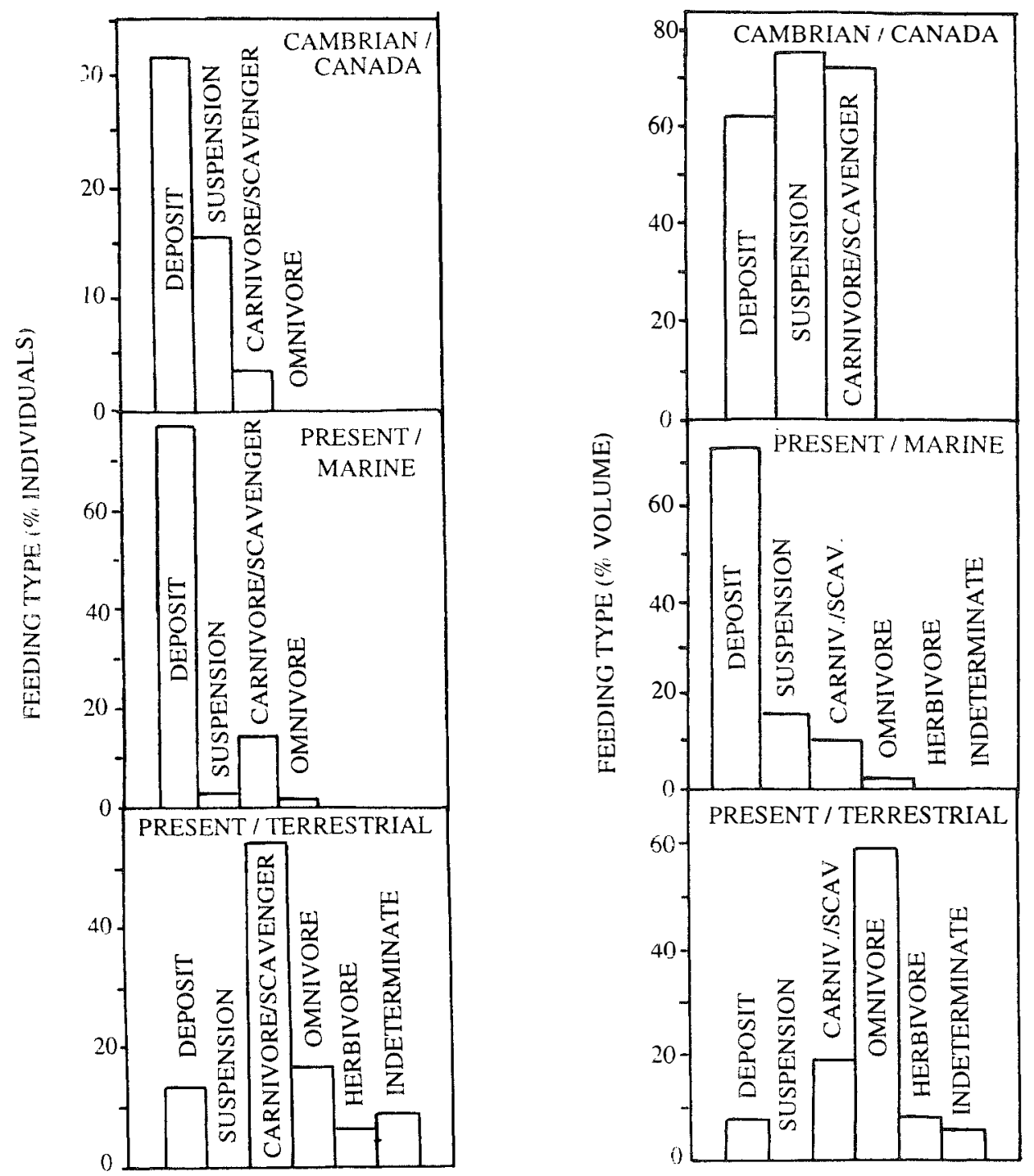

Fig. 4. Proportion (\%) of individuals according to feeding habit in a marine Cambrian community and modern marine and terrestrial communities. Equivalent values for biovolume appear in second part of Fig.

Body length: Species with small bodies dominated all communities numerically. The B. Shale community had more medium and large-bodied animals than Chengjiang and than the modern marine habitat (Fig. 6) (Note: for modern marine habitat: Cyprideis pacifica (Crustacea) is under $3 \mathrm{~mm}$ in length,
Bodotriinae sp. 1 (Crustacea), Mediomastus californiensis (Polychaeta), Turbellaria sp. 1 and Oligochaeta sp. 1 are in the 3-19 mm range, Lumbrineris tetraura (Polychaeta) is in the 20-35 $\mathrm{mm}$ range and Paraprionospio pinnata (Polychaeta) is above $36 \mathrm{~mm}$ long). 


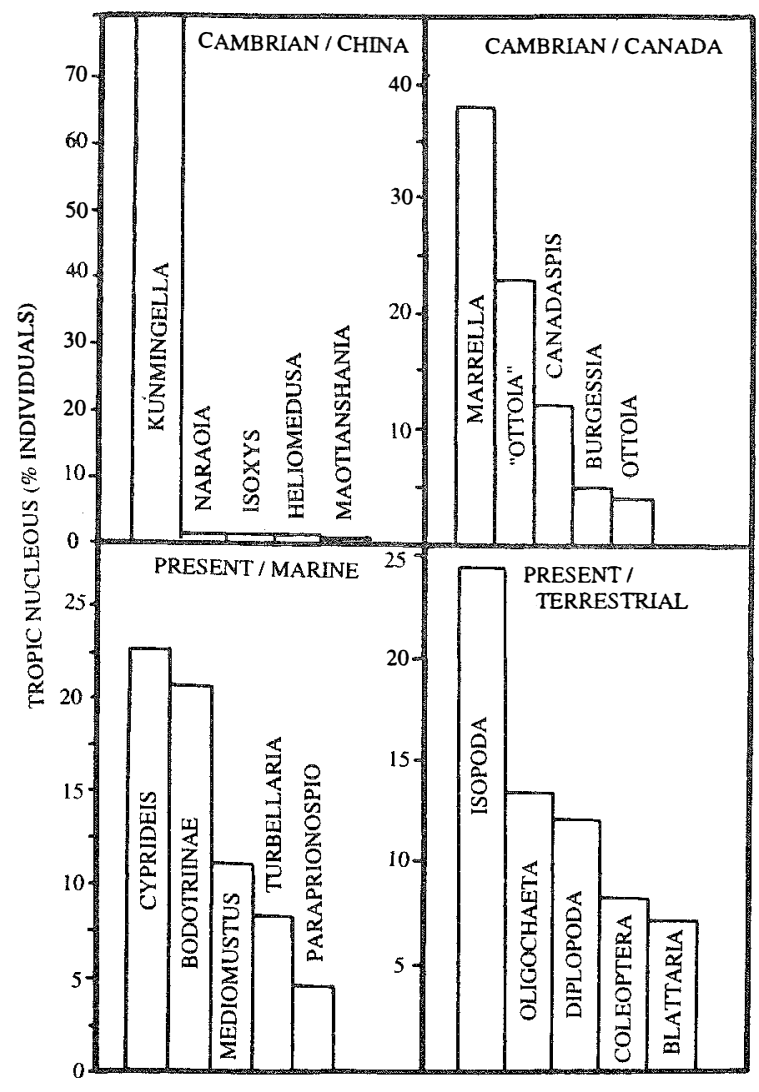

Fig. 5. Proportion (\%) of individuals in the trophic nucleus (see text for definition) of Cambrian and modern marine communities, and in a modern terrestrial community.

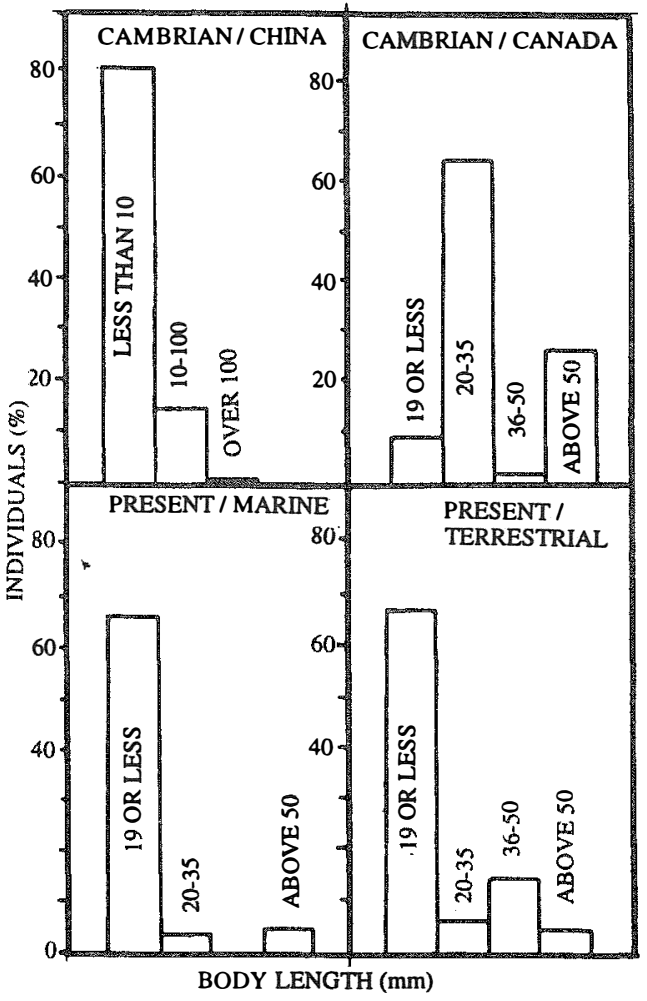

Fig. 6. Proportion (\%) of individuals by body length category in marine Cambrian and modern communities and in a modern terrestrial community.

\section{Comparison of Cambrian onychophoran communities with a modern terrestrial onychophoran community}

Individuals and biovolume by taxa, and fossilization potential: The following trends are similar for number of individuals and volume: arthropods were numerically important in all communities, but the Oligochaeta are significant only in the modern terrestrial community where, even if not as outstanding in number of individuals, molluscs also represent a significant part of the biovolume (Table 2, Fig. 2). In this terrestrial community, the bodies are not as hard as the calcareous parts of a bivalve, but $75 \%$ of individuals are intermediate in fossilization potential (mainly arthropods) and $25 \%$ only have soft parts (e.g. hirudineans).

In the B. Shale community onychophorans were only $0.042 \%$ of individuals (calculated from data in Whittington 1978 and Conway Morris 1986). In Chengjiang the value was $1 \%$, much closer to the modern terrestrial community where $0.83 \%$ were ony chophorans (Table 2).

Habitat: Epifaunal vagrant species were dominant in both communities (Table 2, Fig. 3). 
In comparison with the Cambrian, the modern terrestrial onychophoran community has slightly more infaunal vagrant individuals (sessile taxa are absent). In biovolume the sessile epifauna dominated the Cambrian and the vagrant epifauna the modern community.

Feeding habit: In comparison with the Cambrian, in the terrestrial community, carnivores-scavengers dominate and deposit feeders are less frequent and limited to oligochaetes (Table 2, Fig. 4). However, carnivores-scavengers occupy less biovolume. Some feeding categories that are important in the terrestrial community (including the dominant omnivores) were not identified in the Cambrian specimens.

Trophic nucleus: In both communities the trophic nucleus was dominated by arthropods (Table 2, Fig. 5). In the Cambrian, he- michordates and priapulids were also important. In the modern terrestrial community, oligochaetes are part of the nucleus which is dominated by arthropods (isopods).

Length: The terrestrial community is clearly dominated by small-bodied animals and has less large and medium sized specimens than the Cambrian community (Table 2, Fig. 6).

Fossil morphometry: The basic morphometric data from nine Microdictyon sinicum, five Cardiodityon catenulum, two Hallucigenia fortis and one Luolishania longicruris appear in Table 3. There is a positive but insignificant correlation between body length and number of leg pairs in fossil onychophoran species, and the correlation coefficient is within the range of extant species when males and females are considered independently (Fig. 7).

TABLE 2

Characteristics of a modern terrestrial onychophoran community (Coronado, San José, Costa Rica).

\begin{tabular}{|c|c|c|c|c|c|c|}
\hline Taxon & $\begin{array}{l}\text { Biovolume } \\
(\% \mathrm{ml})\end{array}$ & $\begin{array}{l}\text { Individuals } \\
(\%)\end{array}$ & $\begin{array}{l}\text { Size } \\
\text { class }\end{array}$ & Habitat & $\begin{array}{l}\text { Fossilization } \\
\text { potential }\end{array}$ & Diet \\
\hline Acari & 1.83 & 0.28 & 1 & Epifauna & Low & Carnivore \\
\hline Araneae & 0.99 & 4.96 & 1 & Epifauna & Low & Carnivore \\
\hline Blattaria & 3.69 & 7.16 & 1 & Epifauna & Low & Omnivore \\
\hline Chilopoda & 2.15 & 4.96 & 2 & Epifauna & Low & Carnivore \\
\hline Coleoptera & 4.24 & 8.26 & 1 & Epifauna & Low & Several \\
\hline $\begin{array}{l}\text { Coleoptera } \\
\text { (larvae) }\end{array}$ & 1.83 & 6.06 & 1 & Infauna & Very low & Scavenger \\
\hline Collembola & 0.07 & 2.48 & 1 & Epifauna & Low & Herbivore \\
\hline Dermaptera & 0 & 0.28 & $\mathbf{M}$ & Epifauna & Low & Omnivore \\
\hline Diplopoda & 2.26 & 12.1 & 1 & Epifauna & Low & Scavenger \\
\hline Diptera & 1.83 & 0.55 & 1 & Epifauna & Low & Several \\
\hline Formicidae & 0.58 & 2.48 & 1 & Epifauna & Low & Omnivore \\
\hline Gastropoda & 3.65 & 1.65 & 1 & Epifauna & High & Herbivore \\
\hline Grillidae & 3.83 & 1.1 & $1 \& 2$ & Epifauna & Low & Herbivore \\
\hline Hemiptera & 22.6 & 2.75 & 1 & Epifauna & Low & Omnivore \\
\hline Hirudinea & 0 & 0.28 & $\mathbf{M}$ & Epifauna & Very low & Carnivore \\
\hline Isopoda & 8.98 & 24.5 & 1 & Epifauna & Low & Scavenger \\
\hline $\begin{array}{l}\text { Lepidoptera } \\
\text { (larvae) }\end{array}$ & 0.73 & 1.38 & 1 & Epifauna & Very low & Herbivore \\
\hline $\begin{array}{l}\text { Lepidoptera } \\
\text { (pupae) }\end{array}$ & 0.37 & 0.28 & 2 & Epifauna & Low & None \\
\hline Oligochaeta & 7.67 & 13.5 & 3 & Infauna & Very low & Scavenger \\
\hline Onychophora & 0.73 & 0.83 & 3 & Epifauna & Low & Carnivore \\
\hline Opiliones & 32 & 4.13 & $4 \& 6$ & Epifauna & Low & Omnivore \\
\hline
\end{tabular}

Size classes (length): 1: under $3 \mathrm{~mm}, 2: 3-19 \mathrm{~mm}, 3: 20-35 \mathrm{~mm}, 4: 36 \mathrm{~mm}$ or higher. M: missing value. Adapted from Monge-Nájera and Alfaro (1995). 
TABLE 3

Number of body wall folds and morphological measurements of fossil onychophorans (in $\mathrm{cm} \times 10^{-2}$ ) made on the $A$ anterior, $M$ medium and $P$ posterior part of each animal.

Microdictyon sinicum (nine individuals)

$\begin{array}{lccc}\text { Variable } & \begin{array}{c}\text { Sample } \\ \text { size }\end{array} & \text { Mean } & \text { Range } \\ \text { Body diameter A } & 7 & 16 & \\ \text { Body diameter M } & 7 & 21 & 13-21 \\ \text { Body diameter P } & 7 & 21 & 13-34 \\ \text { Maximum leg width A } & 6 & 6 & 3-9 \\ \text { Maximum leg width M } & 5 & 6 & 3-8 \\ \text { Maximum leg width P } & 5 & 7 & 3-9 \\ \text { Leg length A } & 5 & 37 & 18-51 \\ \text { Leg length M } & 5 & 44 & 15-62 \\ \text { Leg length P } & 5 & 42 & 16-60 \\ \text { Scute height A } & 9 & 13 & 6-22 \\ \text { Scute height M } & 8 & 16 & 9-24 \\ \text { Scute height P } & 7 & 15 & 9-24 \\ \text { Scute width A } & 9 & 11 & 7-22 \\ \text { Scute width M } & 8 & 10 & 7-15 \\ \text { Scute width P } & 7 & 12 & 7-18 \\ \text { Distance between legs A } & 4 & 10 & 5-14 \\ \text { Distance between legs M } & 5 & 17 & 9-23 \\ \text { Distance between legs P } & 5 & 14 & 6-27 \\ \text { Distance between scutes A } & 9 & 9 & 4-18 \\ \text { Distance between scutes M } & 8 & 13 & 6-22 \\ \text { Distance between scutes P } & 7 & 9 & 4-14 \\ \text { Claw length A } & 1 & 5 & \\ \text { Claw length P } & 3 & 3 & 2-4 \\ \text { Folds per segment A } & 1 & 6 & \\ \text { Folds per segment M } & 1 & 6 & \\ \text { Folds per segment P } & 1 & 6 & \\ & & & \end{array}$

Cardiodictyon catenulum (five individuals)

Variable

Sample Mean Range

Body diameter $\mathrm{A}$

Body diameter $\mathrm{M}$

Body diameter $\mathrm{P}$

Maximum leg width A

Maximum leg width $M$

Maximum leg width $P$

Leg length $A$

Leg length $M$

Leg length $P$

Scute height A
Scute height $\mathbf{M}$

Scute height $P$

Scute width A

Scute width $M$

Scute width $\mathrm{P}$

Distance between legs A

Distance between legs M 2

Distance between legs $P \quad 2$

Distance between scutes A 5

Distance between scutes M 4

Distance between scutes $P \quad 4$

Claw length A

Claw length $M$

Claw length $P$

Folds per segment A

Hallucigenia fortis (two individuals)

Variable

Sample Mean Range

Body diameter A

Body diameter $\mathrm{M}$

Body diameter $\mathrm{P}$

Maximum leg width A

Maximum leg width $M$

size

Maximum leg width $P$

Leg length $A$

Spine length A

Spine length $P$

Spine width (at base) A

2-7

$3-6$

3-5

Spine width (at base) $P$

9-11

Distance between spines A

Distance between spines M 2

Distance between spines $\mathrm{P}$

11-12

Luolishania longicruris (one individual)

Variable

Sample Value
size

Body diameter $\mathrm{A}$

Body diameter $\mathrm{M}$

Body diameter $\mathrm{P}$

Distance between legs $\mathrm{P}$

Folds per segment A $\quad 1 \quad 5$

Folds per segment $\mathrm{M} \quad 1 \quad 7$

Folds per segment $\mathrm{P} \quad 1 \quad 4$ 


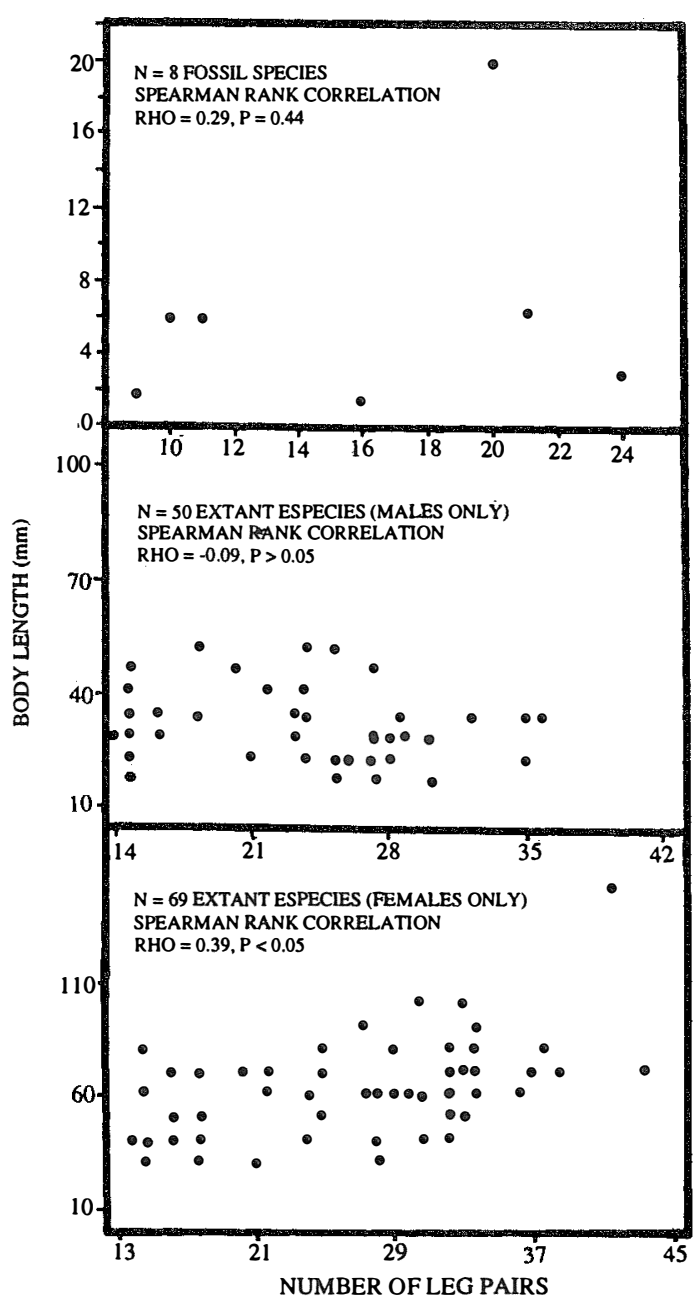

Fig. 7. Plot of the relationship between body length and number of leg pairs in fossil and extant onychophorans. Maximum values were used for each species. Data sources: Hou pers. observ., Hou and Bergström (1995), Monge-Nájera (1994a) and Monge-Nájera (1995).

\section{Speed and weight estimates for fossil} species: In the living species for which data are available (Table 4), speed was more correlated with the number of legs (Rho $=-0.62$ ) than with length $($ Rho $=-0.27)$ but neither is significant $(\mathrm{p}=0.21$ and $\mathrm{p}=0.58$ respectively; Fig. 8). Nevertheless, the speed-number of legs regression allowed a rough estimate of speed in fossil taxa (Table 4). When compared with the cladograms of Fig. 9, it suggests that earlier forms tended to move faster if the Monge-Nájera (1995) cladogram is correct, but there is no clear trend if the Hou and Bergström (1995) cladogram is used. The fossil species might have had individual weights ranging between $100 \mathrm{mg}$ in the case of Luolishania longicruris (the weight of an Epiperipatus biolleyi of similar size, Monge-Nájera and Morera 1994) and more than $5000 \mathrm{mg}$ in the case of the $20 \mathrm{~cm}$ long Xenusion (one of the largest onychophorans, Epiperipatus torquatus, can reach $15 \mathrm{~cm}$ and $4000 \mathrm{mg}$, Read 1985). A recently discovered and still undescribed Costa Rican species (Limón Province) measures $20 \mathrm{~cm}$ in length, equal to the fossil Xenusion.

\section{TABLE 4}

Basic body characteristics and estimated walking speed of fossil onychophorans calculated from the speed of living species with the equation: Speed $=88.62-(2.13)$ (number of leg pairs). Equation produced by a simple reggresion procedure applied to data in this table.

Taxon

$$
\begin{array}{lll}
\begin{array}{l}
\text { Speed } \\
(\mathrm{cm} / \mathrm{min})
\end{array} & \begin{array}{l}
\text { Length } \\
(\mathrm{cm})
\end{array} & \begin{array}{l}
\text { Leg } \\
\text { pairs }
\end{array}
\end{array}
$$

Fossil taxa

$\begin{array}{llll}\text { Hallucigenia } & 69 & 1.7 & 9 \\ \text { Aysheaia } & 67 & 6 & 10 \\ \text { Microdictyon } & 67 & 4.6 & 10 \\ \text { Onychodictyon } & 65 & 6 & 11 \\ \text { Luolishania } & 55 & 1.5 & 16 \\ \text { Xenusion } & 46 & 20 & 20 \\ \text { Helenodora } & 44 & 6.4 & 21 \\ \text { Cardiodictyon } & 37 & 3.1 & 24\end{array}$

\section{Living taxa}

\begin{tabular}{|c|c|c|}
\hline Peripatopsis sp. & 60 & 6 \\
\hline Epiperipatus biolleyi & 60 & 22 \\
\hline $\begin{array}{l}\text { Epiperipatus imthurni } \\
\text { Macroperipatus }\end{array}$ & 12 & 25 \\
\hline torquatus & 11 & 100 \\
\hline $\begin{array}{l}\text { Epiperipatus } \\
\text { trinidadensis }\end{array}$ & 5.5 & 21 \\
\hline
\end{tabular}

Regression equation data: $\mathrm{N}=5$, adjusted $\mathrm{r}^{2} 0.30$, RMS residual 23, intercept $\mathrm{p}=0.1$, leg pairs $\mathrm{p}=0.2$, prediction error when equation is applied to original living species data 10-91\%. Fossil data: Hou pers. observ. and MongeNájera 1995; living taxa data from Manton 1953, Read 1985 and Monge-Nájera et al. 1993. 


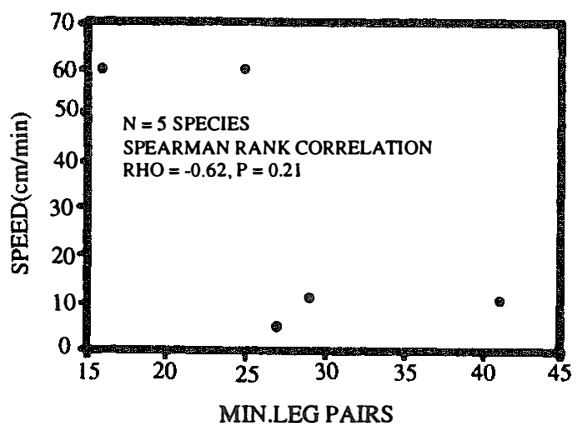

Fig. 8. Plot of the relationship between speed and number of leg pairs in living onychophoran species (used as basis for estimates in fossil onychophorans). Data sources in Table 4.

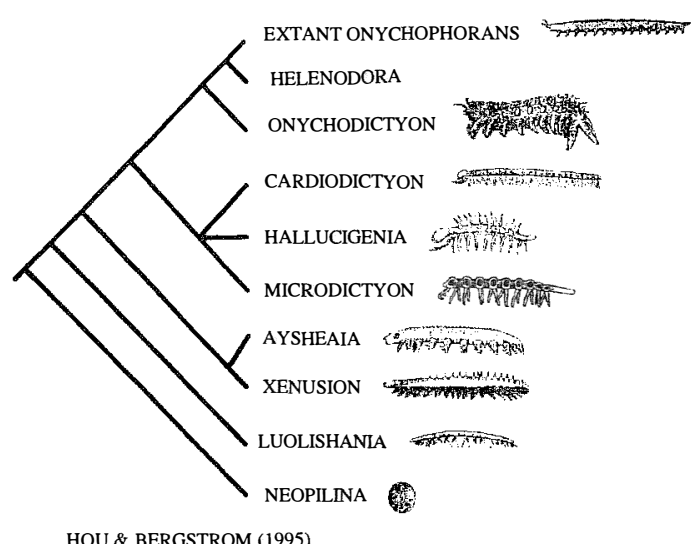

HOU \& BERGSTROM (1995)

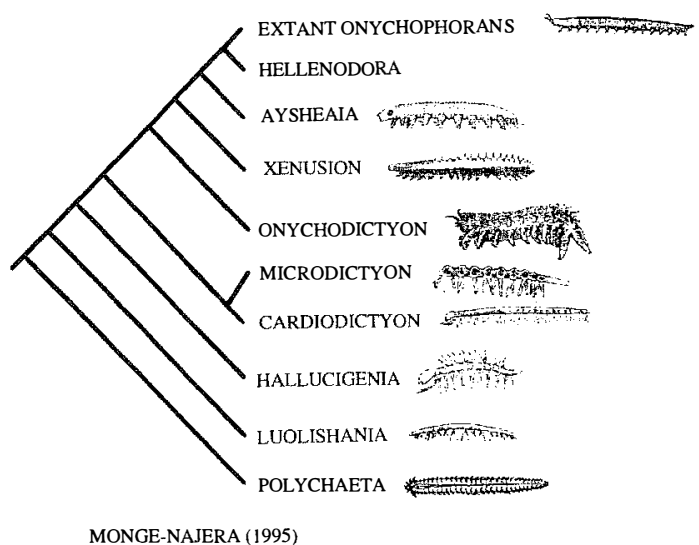

Fig. 9. Two hypotheses about the evolutionary relationships of fossil onychophorans (from Hou and Bergström 1995 and Monge-Nájera 1995).

\section{DISCUSSION}

Community comparisons: This analysis addresses only the general patterns because more detailed statistical enquires seem unwarranted for data from such different methodologies as fossil counts and observation of living organisms.

Number of genera: Genera are categories that reflect the opinions of taxonomists but we consider them to be rough estimates of biodiversity. They suggest that Cambrian tropical mudflats favored the adaptive radiation of two deeply different groups: the highly vagile and complex arthropods and the sessile and simpler poriferans. Why arthropods were so obviously replaced as dominant members of the community by polychaetes (with vagile and sessile taxa) deserves attention in the future (see Fauchald 1975).

Biodiversity and equitability in B. Shale were within the modern seasonal ranges of $P$. Morales (H' 1.61-3.36, $\mathrm{J}=0.46-0.87$; Vargas 1987, $1988 \mathrm{a}, \mathrm{b}$ ), and in Chengjiang $\mathrm{H}^{\prime}$ was low but $\mathrm{J}$ was also within the modern range. If B. Shale followed the modern community pattern (Vargas 1988 b) biodiversity was higher during a rainy season, when nutrient concentrations increased.

The advantages of rapid displacements and an exoskeleton may explain the success of arthropods from the Cambrian to the modern marine and terrestrial communities, both in population and biovolume. Onychophoran abundance is similar in modern terrestrial communities and in Chengiiang, possibly because onychophorans did not evolve tracheal valves to control water loss on land (Monge-Nájera and Lourenço 1995). The rarity of onychophorans in B. Shale stresses the difference between this site and Chengjiang.

\section{Fossilization potential:}

The low proportion of species with hard parts in B. Shale (14\%, see Conway Morris 1986) indicates that similar communities for which only hard parts are known were greatly undersampled by fossilization, in contrast with Chengjiang where fossilization potential was 
extraordinarily high according to our results (50\% of taxa had hard body parts).

Less than $30 \%$ of the modern marine macrobiota has a significant fossilization potential in temperate areas (see Conway Morris 1986). Our tropical data indicate lower values for modern marine species and individuals, and an even worse fossilization potential for terrestrial communities. Marine and terrestrial fossil deposits of tropical origin should be considered even less representative than deposits produced by temperate taxa.

Some early Cambrian taxa later lost hard parts, reducing fossilization potential (Conway Morris 1985); the same trend was noticed in onychophorans (Monge-Nájera 1995). The similarity of onychophoran mandibles with some microfossils labeled as "conodonts" has been mentioned (Monge-Nájera 1995) but remains to be studied in detail.

The reason why the B. Shale organisms soon stopped decomposing is unknown but anoxic or deep sea cold water conditions have been mentioned as a possibility (Conway Morris 1986), albeit the subject is controversial (Orr et al. 1998). However, the anoxia hypothesis is consistent with the discovery that tropical mudflats become anoxic with some periodicity (Alongi 1989) and makes the deep sea hypothesis of Conway Morris (1986) unnecessary. The detailed preservation of structures in both Cambrian communities (Hou and Bergström 1997) indicates that scavengers and bacteria, even if anaerobic bacteria were present as suggested by Briggs (1999) did not cause significant damage.

Individuals and biovolume by taxa: When individuals and biovolume are examined, the pattern becomes more complicated because molluscs and polychaetes respectively replace or approach arthropods as the dominant group.

Seasonality and density data are lacking for B. Shale, but considering its overall ecological similarity with the modern community, it may have been characterized by densities around 40000 macroinvertebrates per square meter, reproductive patterns that ranged from seasonal peaks to a continuous reproductive effort, a relatively constant taxonomic composition and a population dynamics affected mainly the amount of organic matter that in turn reflected the proportion of silt, clay and shell fragments (see Vargas 1987, 1988 a, b, Alongi 1989).

Habitat: In contrast with the modern marine community the B. Shale fossils include epifaunal and nektobenthic species that Conway Morris (1986) suggested had been accidentally included during the deposit formation. However, it is improbable that their presence was accidental because the same trend was found in Chengiiang. Apparently natural selection favored a migration from the surface to life inside the sediment, maybe to escape from increasing predator pressure; the same can explain why sessile taxa began to disappear from the mudflats. Sponges and tunicates are sessile and exposed but have little edible tissue or are chemically protected (J.A. Vargas 1999 pers. comm.). To our knowledge, the literature does not deal with why onychophorans became extinct in marine habitats. These results suggest the working hypothesis that domination of the infaunal habitat by polychaetes deprived onychophorans of the burrowing habitat that they need (see 'Monge-Nájera et al. 1993, Monge-Nájera 1995). In that case, only the species that adapted to land -via the intertidal zone- survived (Monge-Nájera 1995).

Life on land resembles more closely the habitat distribution of Cambrian communities than distribution of modern marine communities because the epifauna predominated in both. Again, predation may have played a role, but there are not enough data to evaluate the idea.

Feeding habits: Modern infaunal communities, in which energy and matter are exported more by larvae than by macropredators, are composed mainly of small opportunists that are surface deposit and suspension feeders (Alongi 1989) in food webs based on 
microalgal detritus and coastal vegetation debris (Vargas 1987). The Cambrian coastal communities seem to have been similar except for the input of terrestrial vegetation remains that were nonexistent at that time (the basis of the food web were strictly algae, Conway Morris 1986). Predator biovolume was high $(52 \%)$, but by number of individuals it was similar to recent communities (Conway Morris 1986). The reduction of suspension feeding in the modern community apparently reflects the absence of sponges, while the absence of omnivores and herbivores in B. Shale may simply be the result of our ignorance about the diets of fossil species and not a real ecological condition.

A greater difficulty in finding and extracting nutrients from the soil than from inundated marine sediments might explain why deposit feeding is less important on land, where carnivory, scavenging and omnivory (associated with high motility and life over the substrate) became more important.

Trophic nucleus: Trophic nucleus (80\% of biomass, individuals necessarily in this case) were compact: a few but common species dominated, similar to modern temperate (Conway Morris 1986) and tropical (Vargas 1987) communities. In B. Shale, the numerically dominant species did not compete for food (Conway Morris 1986), but in Chengjiang and the modern community the dominant species shared feeding habits.

No adjacent species in trophic nucleus share a feeding habit, phytoplankton and benthic algae were the base of the food web (Conway Morris 1986). Ecological displacement, apparent in B. Shale (Conway Morris 1986), lacks evidence in Chengjiang and the terrestrial community. The only quantitative study of the biota associated with modern onychophorans refers to Epiperipatus biolleyi in Coronado, Costa Rica and shows that a significant variety of taxa share feeding guilds (Monge-Nájera 1995).

Length, oncopods and speed: The evolution of larger body sizes may increase the pro- bability of surviving predator attacks but obviously this line of defense was not developed in the mud flat or the terrestrial community. If fish became the main marine predators, burrowing may have been an easier strategy for invertebrates than trying to outcompete vertebrate size.

The fossil values of (1) body length number of legs relationship and (2) body sizes that fit equivalent living species ranges lend further support to interpreting lobopods as onychophorans (Hou and Bergström 1995, Monge-Nájera 1995, Tait et al. 1995). A hypothetical relationship with tardigrades (e.g. Chen et al. 1995), favored by Fortey et al. (1996), is not supported by our morphometric analysis. A detailed cladistic analysis also failed to find a close relationship between onychophorans and tardigrades (Monge-Nájera 1995). Common methodological errors in cladism were discussed by Rouse and Fauchald (1995).

The inferred greater speed of earlier forms is in agreement with the general trend proposed earlier on morphological evidence: later forms used burrowing rather than armoring and high speed for protection (Monge-Nájera et al. 1993, Monge-Nájera 1995).

Cladograms: Although the two available cladograms for fossil onychophorans (Fig. 9) are similar in showing Helenodora as derived ("advanced") and Luolishania as underived ("primitive") and in the associations XenusionAysheaia and Microdictyon-Cardiodictyon, they also differ significantly, perhaps because they used different outgroups. In any case, species hypothesized to move faster because they had less legs tend to have developed scutes as well as large and strong spines. Monge-Nájera (1995) suggested that the evolution of life in microcaverns made long legs, scutes and spines a disadvantage and suggested that the top speed of fossil species was under the $6-34 \mathrm{~cm}$ $/$ min of living $E$. biolleyi. Our speed estimates, based on measurements in air, are higher but under water the viscosity of the medium would result in reduced speed (Manton 1953). 
Implications for the "explosion"-disparity-decimation model: Few recent papers seem to support the explosion model, among them Geyer (1998), Holland (1998) and Valentine et al. (1999) while most authors reject it on the basis of molecular (Bromham et al. 1998, Hoshiyama et al. 1998, Regier and Schultz 1998, Smith 1998) or morphological evidence (Wills 1998 a,b). The remarkably "modern" ecological organization of B. Shale was described years ago (Briggs and Whittington 1985, Conway Morris 1986), but that finding could not be generalized for lack of equivalent data from other Cambrian sites. Our results for Chengjiang not only suggest that a mature ecological community structure was generalized during the Cambrian, but even show that Cambrian biodiversity and equitability indices were surprisingly close to modern values. The fact that niches rather than organisms were similar is not unexpected because this is frequent in modern communities (Barrientos and Monge-Nájera 1995). However, this finding should not be exaggerated: there were also some important differences between the two Cambrian sites, which were distant both in time and geographically. Hypotheses about the scarcity of pre-Cambrian fossils of ten refer to lack of hard parts, small size and destruction of plankton fossils (Fortey et al. 1996). Our finding that even early Cambrian communities were complex and indicative of a long evolutionary history, is consistent with the three hypotheses -which are not mutually exclusive- but indicates a post-Cambrian loss of hard parts in onychophorans.

Strange fossils such as Hallucigenia, described as a leg-less cylindrical animal that anchored itself to the bottom with movable spines and fed with several tentacles that had individual "gullets" (Conway Morris 1977) were the basis for the idea of a rapid increase in morphological disparity, later decimated when only a few body organizations survived (Gould 1989). However, when additional material was found, it became clear that
Hallucigenia was not a new phylum but an onychophoran: the spines were dorsal (defenses) and the "tentacles" were ventral legs (Hou et al. 1991). The same applies to other groups (Hou and Bergström 1995, Hou et al. 1995, Fortey et al. 1996) and weakens the disparity explosion-decimation model, which nevertheless was very useful as a motivation for additional work (the present paper being an example). Our results agree with recent morphospace disparity studies (Wills 1998 a,b). The taxonomic diversity, morphological disparity and geographic distribution of onychophorans (Hou and Bergström. 1995, Monge-Nájera 1995) indicate a significant pre-Cambrian evolutionary history that also fails to support the explosion model. However, even though disparity among phyla was not as important as the model predicts, at least for onychophorans morphological disparity within the phylum was greater than it is today (Monge-Nájera and Hou 2000). The reduction in onychophoran morphological disparity may have been associated with migration into the sediment when large predators evolved, because life in burrows can favor the evolution of simple, cylindrical body shapes (see Monge-Nájera 1995).

\section{ACKNOWLEDGMENTS}

We thank José A. Vargas Z. for particularly valuable assistance and support; Bernal Morera, Harlan Dean and Sergio Salazar Vallejo for providing valuable literature and information; Zaidett Barrientos LL. and Fernando Barrientos LL. for field assistance; Karina Rodríguez, Juan C. Solano and V. Arias for laboratory assistance, Marisol Rodríguez for the illustrations; Alvaro Wille and Bernal Morera for supporting the senior author's interest in onychophorans and D.E.G. Briggs (University of Bristol), Teresita Aguilar (Universidad de Costa Rica) and several anonymous reviewers, for comments that led us to significantly improve an earlier draft. 


\section{RESUMEN}

Con base en nuevos hallazgos paleontológicos hechos en el sur de China se analiza la controversia sobre la "explosión del Cámbrico" que supuestamente incluyó un gran aumento en la diversidad morfológica, con la aparición de muchos filos que posteriormente se extinguieron. Se compara las comunidades fósiles de Cheng-yiang (China) y Burgess Shale (Canadá) con una comunidad marina similar moderna (Punta Morales, Costa Rica) y con una comunidad terrestre moderna (Coronado, Costa Rica) que al igual que los dos depósitos fosilíferos incluye al filo Onychophora. Se concluye que (1) durante el Cámbrico las comunidades costeras tropicales eran similares a las modernas al punto de que incluso los índices de biodiversidad y equitabilidad eran semejantes a los actuales; (2) la diversidad morfológica y distribución geográfica de los onicóf oros indican una larga historia evolutiva precámbrica que no apoya el modelo de la "explosión"; (3) las diferencias morfológicas entre filos no eran tan importantes como predice el modelo de "explosión seguida de extinción", pero en la caso de los onicóforos, la diversidad morfológica dentro del filo era mayor en el Cámbrico que en la actualidad, y su reducción puede haber estado asociada con la migración al interior del sedimento al evolucionar depredadores de tamaño relativamente grande.

\section{REFERENCES}

Abouheif, E., R. Zardoya \& A. Meyer. 1998. Limitations of metazoan 18S rRNA sequence data: Implications for reconstructing a phylogeny of the animal kingdom and inferring the reality of the Cambrian explosion. J. Molec. Evol. 47: 394-405.

Alongi, D.M. 1989. Ecology of tropical soft-bottom benthos: a review with emphasis on emerging concepts. Rev. Biol. Trop. 37 : 85-100.

Barrientos, Z. \& J. Monge-Nájera. 1995. Geographic homogenity among insect communities in Neotropical paramos: a hypothesis test. Caldasia 18: 49-56.

Bergström, J. 1986. Metazoan evolution - a new model. Zool. Scripta $15: 189-200$.

Briggs, D.E.G. 1999. Molecular taphonomy of animal and plant cuticles: selective preservation and diagenesis. Phil. Trans. R. Soc. Lond. B 354: 7-17.

Briggs, D.E.G. \& H.B. Whittington. 1985. Modes of life of arthropods from the Burguess Shale, British Columbia. Trans. Roy. Soc. Edinburg 76: 149160.
Bromham, L., A. Rambaut, R. Fortey, A. Cooper \& D. Penny. 1998. Testing the Cambrian explosion hypothesis by using a molecular dating technique. Proc. Nat. Acad. Sci. USA 95: 12386-12389.

Chen, J., G. Zhou \& L. Ramsköld. 1995. A new Early Cambrian onychophoran-like animal, Paucipodia gen. nov., from the Chengjiang fauna, China. Trans. Roy. Soc. Edinburgh Earth Sci. 85: 275-282.

Conway Morris, S. 1977. A new metazoan from the Cambrian Burgess Shale, British Columbia. Palaeontology 20: 623-640.

Conway Morris, S.C. 1985. Cambrian Lagerstätten: their distribution and significance. Phil. Trans. R. Soc. Lond. B 311: 49-65.

Conway Morris, S.C. 1986. The community structure of the middle Cambrian phyllopod bed (Burgess Shale). Palaeontology 29: 423-467.

Fauchald, K. 1975. Polychaete plylogeny: A problem in Protostome evolution. Syst. Zool. 23:493-506.

Fortey, R.A., D.E.G. Briggs \& M.A. Wills. 1996. The Cambrian evolutionary 'explosion': decoupling cladogenesis from morphological disparity. Biol. J. Linn. Soc. London 57:13-33.

Geyer, G. 1998. The Cambrian explosion. Palaeont. Zeit. 72: 7-30.

Gould, S.J. 1989. Wonderful life. The Burgess Shale and the nature of history. W.W. Norton, New York. 347 p.

Holland P., W. H. 1998. Major transitions in animal evolution: A developmental genetic perspective. Am. Zool. 38: 829-842.

Hoshiyama,D., H. Suga, N. Iwabe, M. Koyanagi, N. Nikoh, K.I. Kuma, F. Matsuda, T. Hon jo \& T. Miyata. 1998. Sponge Pax cDNA related to Pax- $2 / 5 / 8$ and ancient gene duplications in the Pax family. J. Mol. Evol. 47: 640-648.

Hou, X. 1999. New rare bivalved arthropods from the Lower Cambrian Chengjiang fauna, Yunnan, China. J. Paleont. 73: 102-116.

Hou, X. \& J. Bergström. 1994. Palaeoscolecid wormsmay be nematomorphs rather than annelids. Lethaia 27: 11-17.

Hou, X. \& J. Bergström. 1995. Cambrian lobopodians ancestors of extant onychophorans? Zool. J. Linn. Soc. London 114: 3-19. 
Hou, X. \& J. Bergström. 1997. Arthropods from the lower Cambrian Chengjiang fauna, southwest China. Scandinavian University, Oslo, Norway. 116 p.

Hou, X., J. Bergström \& P. Ahlberg. 1995. Anomalocaris and other large animals in the Lower Cambrian Chengiang of auna of southwest China. GFF 117: 163-183.

Hou, X., L. Ramsköld \& J. Bergström. 1991. Composition and preservation of the Chengjiang fauna - a Lower Cambrian soft-bodied biota. Zool. Scripta 20: 395-411.

Jin, Y., X. Hou \& H. Wang. 1993. Lower Cambrian pediculate lingulids from Yunnan, China. J. Paleontol. 67: 788-798.

Manton, S.M. 1953. Locomotory habits and the evolution of the larger arthropodan groups. Symposia of the Society for Experimental Biology, Evolution 7: 339-376.

Monge-Nájera, J. 1994a. Ecological Biogeography in the Phylum Onychophora. Biogeographica 70 : 111-123.

Monge-Nájera, J. 1994b. Reproductive trends, habitat type and body characteristics in velvet worms (Onychophora). Rev. Biol. Trop. 42: 611-622.

Monge-Nájera, J. 1995. Phylogeny, biogeography and reproductive trends in the Onychophora. Zool. J. Linn. Soc. (London) 114: 21-60.

Monge-Nájera, J. 1996. Jurassic-Pliocene biogeography: testing a model with velvet worm (Onychophora) vicariance. Rev. Biol. Trop. 44: 159-175.

Monge-Nájera, J. \& B. Morera. 1994. Morphological and physiological characteristics of two species of Epiperipatus from Costa Rica (Onychophora: Peripatidae). Rev. Biol. Trop. 42: 181-188.

Monge-Nájera, J. \& J. P. Alfaro. 1995. Geographic variation of habitats in Costa Rican velvet worms (Onychophora: Peripatidae). Biogeographica 71: 97-108.

Monge-Nájera, J. \& W. Lourenço. 1995. Biogeographic implications of evolutionary trends in onychophorans and scorpions. Biogeographica 71: 179-185.

Monge-Nájera, J. \& X. Hou. 2001. Experimental taphonomy of velvet worms (Onychophora): implications for the Cambrian "explosion", disparity and decimation model. Rev. Biol. Trop. (in press.).
Monge-Nájera, J., Z. Barrientos \& F. Aguilar. 1993. Behavior of Epiperipatus biolleyi (Onychophora: Peripatidae) under laboratory conditions. Rev. Biol. Trop. 41: 689-696.

Orr, P.J., D.E.G. Briggs \& S.L. Kearns. 1998. Cambrian Burgess Shale animals replicated in clay minerals. Science 281: 1173-1175.

Read, V.M. St. J. 1985. The ecology of Macroperipatus torquatus (Kennel), with special reference to feeding and a taxonomic review. Ph.D. Dissertation, University of Wales, Bangor, Wales, United Kingdom.

Regier, J.C. \& J.W. Schultz. 1998. Molecular phylogeny of arthropods and the significance of the Cambrian "explosion" for molecular systematics. Amer. Zool. 38: 918-928.

Rhebergen, F. \& S.K. Donovan. 1994. A Lower Palaeozoic 'onychophoran' reinterpreted as a pelmatozoan (stalked echinoderm) column. Atlantic Geol. 30: 19-23.

Rigby, J.K. \& X. Hou. 1995. Lower Cambrian demosponges and hexactinellid sponges from Yunnan, China. J. Paleontol. 69 : 1009-1019.

Rouse, G.W. \& K. Fauchald. 1995. The articulation of annelids. Zool. Scr. 24: 269-301.

Smith, L.H. 1998. Asymmetry of early paleozoic trilobites. Lethaia 31: 99-112.

Sprinkle, J. \& D. Collins. 1998. Revision of Echmatocrinus from the Middle Cambrian Burgess Shale of British Columbia. Lethaia 31: 269-282.

Tait, N.N., D.A. Briscoe \& D.M. Rowell. 1995. Onychophora - ancient and modern radiations. Mem. Ass. Australas. Paleontols. 18: 21-30.

Valentine, J., D. Jablonski \& H. E. Douglas. 1999. Fossils, molecules and embryos: New perspectives on the Cambrian explosion. Development 126: 851859

Vargas, J. A. 1987. Community structure of macrobenthos and the results of macropredator exclusion on a tropical intertidal mud flat. Rev. Biol. Trop. 36: 287-308.

Vargas, J. A. 1988a. The benthic community of an intertidal mud flat in the Gulf of Nicoya, Costa Rica. Description of the community. Rev. Biol. Trop. 35 : 299-316. 
Vargas, J.A. 1988b. A survey of the meiofauna of an Eastern Tropical Pacific mud flat. Rev. Biol. Trop. 36: 541-544.

Vargas, J.A. 1996. Ecological dynamics of a tropical intertidal mudflat community, p. 355-371. In K.F. Nordstrom \& C.T. Roman (eds.). Estuarine Shores: Evolution, Environments and Human Alterations. Wiley, New York.

Whittington, H.B. 1978. The lobopod animal Aysheaia pedunculata Walcott, Middle Cambrian, Burgess Shale, British Columbia. Phil. Trans. Roy. Soc., London B., 284: 165-197.
Wills, M.A. 1998a. Crustacean disparity through the Phanerozoic: Comparing morphological and stratigraphic data. Biol. J. Linn. Soc. 65: 455-500.

Wills, M.A. 1998b. Cambrian and recent disparity: The picture from priapulids. Paleobiology 24: 177-199.

Editor: José A. Vargas

Received 29-IV-1999. Corrected 23-III-2000.

Accepted 24-IV-2000. 